tions by $\mathrm{Dr}$. H. Riesenhuber, Minister for Research and Technology (BMFT), Professor W. Frühwald, President of Germany's research council (Forschungsgemeinschaft), Professor H.F. Zacher, President of the MaxPlanck-Institut, and members of the parliamentary sub-committee for science.

Japan's MITI was held up as a possible model for coordinating funding and it was felt that discussion should be extended to economic and political circles. Another conclusion was that the BMFT does not in fact spend $40 \%$ of its budget on basic research as research is usually mixed up with technical development. While the responsibility for basic research clearly lies at the federal level, the universities "fall between two chairs" since they are supported by both federal and state government. Hence concern about the impact of the BMFT's decision not to extend its 2000 MDM university renewal programme.

Proceedings
Third European
Particle Accelerator Conference (EPAC92)
Berlin 24-28 March 1992
Vols. 1 and 2 (1760 p. in total)
Editors: H. Henke, H. Homeyer
\& C. Petit-Jean-Genaz
Price: SFR 340.-
Directory of
Physics Institutes in Central Europe
By: E.W.A. Lingeman
EPS Committeee for East-West Coordination
Price: SFR 120.-
Orders: EPS Secretariat, Geneva

\section{EPS Notices}

- ERC Proposals Sought

The Steering Committee of the European Research Conferences aims to finalise 1993 physics ERC's at its next meeting in January 1993. K. Bethge who chairs the EPS Working Group on ERC's would like to propose suggestions for 1994 ERC's to the Committee at the meeting. He has written to the Divisions and Groups asking them to suggest titles, dates, location, chairperson, and frequency (annual or biannual) by mid-January 1993. Please contact a Division or Group chairperson if you wish to have a proposal considered.

\section{- Secretariats}

Gero Thomas, the Executive Secretary, will be based full time in Geneva from 1 January 1993. The Society's two full-time staff members in Budapest (Maria Lázár and Judith Török) will continue as at present. The Geneva Secretariat will have Edit Thomas as the assistant to Gero Thomas and Peter Boswell (who mainly edits Europhysics News). Christina Bouldin will continue to be the Staff Editor of Europhysics Letters and to administer the student mobility scheme; Edit Thomas is the replacement Staff Editor and Alica Rowe mainly handles routine aspects. Nadia Sarteur is engaged half-time to do accounts and to help Cornelia Heschel provide general back-up.

The Secretariats' work will be divided up as follows:

- Governing bodies, prizes (G. Thomas); Divisions (M. Lázár).

- Action Committee follow-up: ACAPPI (G. Thomas), Conferences (E. Thomas), Physics \& Society (G. Thomas), Publications (P. Boswell), EWCC (G. Thomas).

- Task forces: finance \& constitution (G. Thomas), student mobility (C. Bouldin), professional qualifications (P. Boswell).

- Europhysics Letters: editorial (C. Bouldin, E. Thomas), routine (A. Rowe), management \& finance (G. Thomas).

- Europhysics News: editorial (P. Boswell), advertising \& orders (P. Boswell, E. Thomas).

- Associate Members: enquiries (P. Boswell); admin. (E. Thomas).

- Individual Members: subscriptions \& enquiries (M. Lázár).
MAG-03MC, MAG-03MS

\section{Three Axis Magnetic Field Sensors}

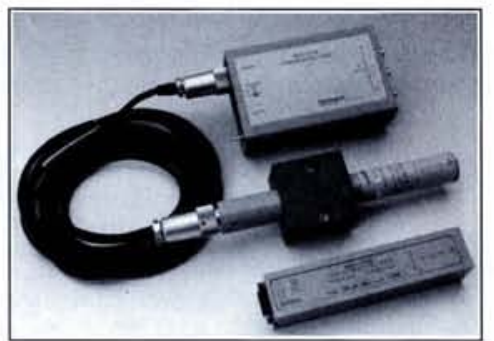

VERSATILE

MAGNETOMETERS

FOR PRECISION

MEASUREMENTS

OF STATIC AND

ALTERNATING

MAGNETIC FIELDS

- Available in four measuring ranges from $\pm 70 \mu \mathrm{T}$ to $\pm 500 \mu \mathrm{T}$

- MAG-03MC - cylindrical version, $202 \mathrm{~mm} \times 25 \mathrm{~mm}$ diameter

- MAG-03MS - square section version, $152 \mathrm{~mm} \times 32 \mathrm{~mm} \times 32 \mathrm{~mm}$

- Analog output - 3 voltages 0 to $\pm 10 \mathrm{~V}$, proportional to $\mathrm{Bx}, \mathrm{By}$ and $\mathrm{Bz}$

Wide bandwidth - dc to $2 \mathrm{kHz}$

- Powered from any $12-18 \mathrm{~V}$ dual supply,

operation over cables to lengths of 600 metres

- MAG-03M power supply unit available

WORLDWIDE NETWORK OF AGENTS AND DISTRIBUTORS

\section{Bartington}

Spendlove Centre. Charlbury. Oxford. OX7 3PQ. England

Tel: +44608 810657 Fax: +44608 811417
- Restructuring Endorsed

The Executive Committee meeting in closed session in Geneva on 11 November decided unanimously to recommend approval of the restructuring scheme outlined in the document $A$ New EPS Structure [EN 23 (1992) 75] presented at the 1992 Council. The Executive continues to harmonise the various elements of a proposal that will be submitted to the next Council Meeting in Nice on 26-27 March 1993. A consultation document that synthesizes inputs from Divisions and Groups and from national societies will be circulated to the societies by the end of 1992 for comment. Financial implications will meanwhile be made more precise, ready for preparation of the final proposal.

\section{- Unit Fee Increase to be Proposed}

According to Rule 34 of the EPS Constitution, the Executive Committee is obliged to submit to all Ordinary Members any proposal to increase the unit fee. This must be done at least three months before placing the proposal before the next Council (in Nice in March) so that IOM's can consult their Delegates.

The Executive decided at its 11 November meeting to propose an increase of the unit fee from SFR 13.50 to SFR 15.00 (an $11.1 \%$ increase) effective from 1 January 1994. Most of the increase represents adjustment for inflation in Switzerland, estimated at $7.5 \%$ for the two-year period starting from the date of the last increase (1 January 1992). The remainder (3.6\%) is to allow just over SFR 30000 .- to be set aside for priority actions run independently of the Secretariat by committees, etc.

\section{- Fee Reduction}

Council by a mail ballot has unanimously decided to amend Rule 35a) of the EPS Constitution as follows:

Ordinary Members shall pay annual fees as follows:

a) Individual Ordinary Members, 8 units per Individual Constitution Article 4a) Ordinary Member

The rule change, which takes effect on 1 January 1993, means that the annual fee for an IOM who is not a member of either a National Society or a Collaborating Society (i.e., an Article 4a member) will decrease from SFR 162.- to SFR 108.-. It has been felt for some time that the relatively high 4 a) fee discriminated against those who for professional reasons choose not to belong to other societies. 